\title{
Study of comparison of antimicrobial potencies of Bauhinia Variegata leave extracts with antibiotics against selected bacteria
}

\author{
Shaymaa .J.Ahmed(Ph.D.) ${ }^{1}$ Rawah. A. Faraj(M.SC. ${ }^{2}$,Rannin Azawi(B.Sc.)3 \\ And Marawa .M.Abdal Al- Kareem(B.Sc. $)^{4}$ \\ ${ }^{1,2,3,4}$ Department Of Anatomy - Collage Of Medicine - Baghdad University - Baghdad - Iraq \\ Department Of Community Health / Institute of Technical Medicine Foundation Of Technical Education
}

\begin{abstract}
Various research have reported that Bauhinia Variegata has anti diabetic activity, good insecticide , antigoiterogenic and better antioxidant activity and it is also reported as anti-inflammatory and immunomodulatory for various inflammatory diseases.

Alcoholic extracts from of Bauhinia Variegata leaves and comparison of antimicrobial potencies with antibiotics against selected gram positive and gram negative bacteria .

The leaves extracts has activity for abroad spectrum against gram -positive and gram negative bacteria and inhibition zone of MIC in diameter $(8-11 \mathrm{~mm})$ Staphylococcus aureus is the lowest and Escherichia coli is the highest .

The present study shows that the Bauhinia Variegata leaves extracts has activity against the gram-positive and gram negative bacteria, so this plant could be utilized as an alternative source of useful antimicrobial drugs .

Key words: Bauhinia Variegata, antibiotics resistance and alcoholic extract leaves
\end{abstract}

\section{Introduction:}

Infection diseases are one of the major causes of health hazard in human and animals . these infections are caused by pathogenic bacteria, virus and fungi severity of infection disease is bases on virulence factors produced by infections agent. In recent years various human pathogenic have been reported to acquire resistance toward the common drugs (1) .

Antibiotics resistance has become a global concern in recent years . this problem is of great significance especially in developing countries because infectious diseases are one of the major causes of mortality in these countries the screening of natural products has been the source of innumerable therapeutic agents.

Higher plants as a source for new potential drugs is still largely unexplored and only a small percentage of them has been subjected to photochemical investigation and the fractions submitted to pharmacological screening is very low (2) .

Bauhinia Variegata L. is a species of flowering plant in the family Caesalpiniaseae . found wild in the subHimalayan tract and outer Himalaya up to 1300 in Punjab. dry deciduous forests , especially on rocky hills throughout India .(1,3,4)

The aim of this study is to determine the MIC ( minimum inhibitory concentration ) and to investigate the antimicrobial activity of against some bacterial isolates .

\section{2-1 Harvesting of the samples :}

\section{Research Methods:}

Bauhinia Variegata_ leaves were collected from Al- Jadria gardens in Baghdad University ( mid September to mid November ) the leaves were initially rinsed with distilled water and dried using towel in the laboratory

All samples were dried at $40 \mathrm{C}^{\circ}$ for 24 hours, ground into powder using grinding machine, then subjected to extraction (5).

\section{2-2 Preparation of leaf ethanol extracts :}

Powdered leaves $(50 \mathrm{gm})$ were soaked into $(250 \mathrm{ml})$ of $70 \%$ ethanol . the mixture was kept for 24 hours in tightly sealed container at room temperature, protected from sun light and mixed several times with a sterile glass rod, the mixture was then filtered through wattman no .1 flitter paper. The extracted liquid was subjected to rotary evaporator in order to remove the solvent (2)

\section{2-3 Microorganism :}

The microorganism which used this study were Escherichia Coli MM 294, Salmonella typhi GEB111and Staphylococcus aurous were used for antibacterial assay (6) . 


\section{2-4 MIC Test :}

In this test, a number of small sterile paper disks of uniform size $(6 \mathrm{~mm})$ that had been impregnated with concentration $20 \mathrm{mg} / \mathrm{ml}$ of leaves extract were placed on the surface of agar plate previously inoculated with a standard amount $1.5 x^{10}$ of the microorganism determined to be tested, the plates were incubated at $37 \mathrm{c}^{\circ}$ for 24 hours. After incubation the plates were examined for the presences of inhibition zone of bacterial growth (clear hallows ) around the dicks (7) .

\section{2-5 Antibiotics resistance :}

The bacterial strains were suspended in nutrient broth loop full was inoculated on the surface of each nutrient agar plates . the antibiotics discs were placed on inoculated plates and at $37 \mathrm{c}^{\circ}$ for 24 hours (8) The antibiotics which used are Ampicillin Soudium ( AMS), Rifampicin (Rif), Oflaxamine (OFX ), Erythromycine (E) Amoxicillin (AM), Tetracycline (TE) and Varcomycine (VA) .

\section{Results}

The results of antimicrobial activity and MIC were carry out on two types of pathogenic microorganism gram positive and gram negative bacteria (Staphylococcus aurous) and gram negative bacteria ( Escherichia coli and Salmonella typhi) were in table -1-

Table (1) Comparison between the Bauhinia Variegata leaves extract and antibiotics

\begin{tabular}{|l|l|l|l|l|l|l|l|l|}
\hline Bacteria & AMS & Rif & Oxf & E & AM & TE & VA & MIC \\
\hline Staphylococcus aurous & 12 & 21 & 21 & 22 & 12 & 23 & 16 & 8 \\
\hline Escherichia coli & 20 & R & 24 & R & 20 & 11 & 12 & 11 \\
\hline Salmonella tyohi & 14 & $R$ & 25 & $R$ & 25 & 28 & 18 & 10 \\
\hline
\end{tabular}

- $\quad \mathrm{MIC}=$ Inhibition Zone Diameter $(\mathrm{mm})$ of Bauhinia Variegata

- $\mathrm{R}=$ Resistance to Antibiotics

\section{Discussion}

Drug Resistance in microbes become a big problem along with the emergence of new infections diseases . Micro-organism acquired resistant against the pharmaceutical drugs by production of drug degrading enzymes , resistant plasmid alteration of metabolic path way (9) .

Table (1) shows the comparisons between the Bauhinia Variegata leaves extracts and the antibiotics activity as we see in this study there is broad spectrum activities against positive and negative gram stain bacteria, the inhibition zone of MIC in diameter $(8-11 \mathrm{~mm})$. Staphylococcus aurous is the lowest and the highest is Escherichia coli.

Escherichia coli. and Salmonella typhi are resistance to Rif and Am but they are sensitive to Bauhinia Variegata leave extract . this result is regarded with Vijay Kumar et al. (1) which they found that the ethanolic extract from the stem Bark of Bauhinia Variegata was effective against gram positive and gram negative bacteria as while as against the fungi (more effective against Aspergillus Fumigates and also is been agreed with Dhale (10) who found that the alcoholic extract of leaves and bark wae effective against gram positive and gram negative bacteria and the antibacterial activities of the leaves and bark were due to presence of various secondary metabolites 


\section{References}

[1] MMJ.Vijay Kumar, B.X. Eswarappa.\& Y.D Bodke. Antimicrobial activity of stem bark of Bauhinia Variegata Linn . American Journal of Pharm Tech Research .Vol.2(1) (2012) : 564-569 .

[2] G.Gunalan, A .Saraswathy, \& V.Krishnamurthy. Antimicrobial activity of medicinal plant Bauhinia Variegata Linn . International Journal of Pharmacy \&Biological sciences Vol.1(4) (2011): 400-408

[3] Anonymous, the Ayurredic pharcopoeia of india Vol.1, the controller of publications ,New Dehli, 2001 . 321 -322 .

[4] R.Gupta, P.m. Paarakh, \& V. Gavani

[5] Pharmacognostical \& phytochmical screening of Bauhinia Variegata Linn . leaves . Journal of pharmacy research 2 (7) (2009): 1196-1198.

[6] K. Bauer, D. Garbe\& H. X Surburj . common Fragrance and flavor materials . (1997) $3^{\text {rd }}$ ed . Germany . Wiley - VCH

[7] S h.J. Ahmed " the transfer of genetic and immune determinant to and genetic improvement of Salmonella typhyi strain used as oral vaccine

[8] (M.Sc .thesis ) (1997). Collage of sciences . Baghdad university .

[9] S.O. Oyedem, G. Pirochenva, L.V. Mabinya, G. Bradley, \& A.J. Afoayan . composition and comparisons of antimicrobial potencies of some essential oils and antibiotics against selected bacteria . African .J.Biotech. 7(22) (2008) : 4140-4146 .

[10] K .Mounchid , F. Boujilat, , N. Dersi, T .Abonssaouira, A Rachidai, A.Tantaoui- Elaraki, \& M. Alaoui-Ismailia. The susceptibility of Escherichia coli

[11] Strains to essential oils of Rosemarinus officinalis and Eucalyptus globules.

[12] African J. Biotech. 4(10) (2005): 1175-1176.

[13] RE.Lanski. Bacterial evaluation and the cost of antibiotic resistance . international Microbial 1(1998): 265- 270.

[14] D .A. Dhale . phytochmical screening and antimicrobial activity of Bauhinia Variegata linn . journal of Ecobiotechnology 3(9) (2011) : 04-07 